$5-7-2020$

\title{
"You Feel Like You Belong Nowhere": Conflict-Related Sexual Violence and Social Identity in Post-Genocide Rwanda
}

\author{
Myriam Denov \\ McGill University \\ Laura Eramian \\ Dalhousie University \\ Meaghan C. Shevell \\ McGill University
}

Follow this and additional works at: https://digitalcommons.usf.edu/gsp

\section{Recommended Citation}

Denov, Myriam; Eramian, Laura; and Shevell, Meaghan C. (2020) "'You Feel Like You Belong Nowhere": Conflict-Related Sexual Violence and Social Identity in Post-Genocide Rwanda," Genocide Studies and Prevention: An International Journal: Vol. 14: Iss. 1: 40-59.

DOI:

https://doi.org/10.5038/1911-9933.14.1.1663

Available at: https://digitalcommons.usf.edu/gsp/vol14/iss1/6

This Articles is brought to you for free and open access by the Open Access Journals at Digital Commons @ University of South Florida. It has been accepted for inclusion in Genocide Studies and Prevention: An International Journal by an authorized editor of Digital Commons @ University of South Florida. For more information, please contact digitalcommons@usf.edu. 


\title{
"You Feel Like You Belong Nowhere": Conflict-Related Sexual Violence and Social Identity in Post-Genocide Rwanda
}

\author{
Myriam Denov \\ McGill University \\ Montreal, Quebec, Canada \\ Laura Eramian \\ Dalhousie University \\ Halifax, Nova Scotia, Canada \\ Meaghan C. Shevell \\ McGill University \\ Montreal, Quebec, Canada
}

Accounts of the 1994 Rwandan genocide most often highlight its close-contact massacres as neighbors attacked neighbors, with less attention given to the reality of sexual violence. Nowrojee ${ }^{1}$ and Sharlach ${ }^{2}$ note propaganda which specifically targeted Tutsi women as sexual objects and mass rape was an integral feature of the genocide. An estimated ninety percent of Tutsi women and girls who survived the genocide experienced sexual violence by the interahamwe youth militias, by agents of the state, or by civilians. ${ }^{3}$ This sexual violence was perpetrated with genocidal intent, as part of the broader agenda seeking to destroy the Tutsi population. ${ }^{4}$ Mass rape during the genocide had lasting effects on survivors, including physical injury, psychological scars, stigma, and socioeconomic marginalization. ${ }^{5}$

Sexual violence also had a powerful intergenerational effect, as evidenced by the realities and experiences of children born of conflict-related sexual violence. Estimates reveal between 10,000 and 25,000 children were born of rapes committed during the Rwandan genocide, although these figures are challenging to establish due to the paucity of systematic data. ${ }^{6}$ While still a burgeoning

${ }^{1}$ Binaifer Nowrojee, Shattered Lives: Sexual Violence During the Rwanda Genocide and Its Aftermath (New York: Human Rights Watch, 1996).

2 Lisa Sharlach, "Gender and Genocide in Rwanda: Women as Agents and Objects of Genocide," Journal of Genocide Research 1, no. 3 (1999), 387-399.

${ }^{3}$ Rachel Rinaldo, "Rights-Rwanda: Women Survivors of the Rwandan Genocide Face a Grim Reality," Inter Press Service, April 6, 2004, accessed October 10, 2019, http://www.ipsnews.net/2004/04/rights-rwanda-women-survivors-of-therwandan-genocide-face-grim-realities/.

${ }^{4}$ Given the genocidal intent and its objective of destroying an entire group through sexual violence, it could be argued that "genocidal rape" differs from the broader category of conflict-related sexual violence. While an in-depth discussion of this is beyond the scope of this paper, we suggest that such distinctions may be questionable. First, such distinctions may produce rigid binaries that are unhelpful to understanding conflict-related sexual violence as a whole. Second, research has shown that there are remarkable similarities in experiences and realities of children born of war/genocide more than there are differences. Whether in Rwanda where a genocide took place, or in northern Uganda and Sierra Leone, where conflicts were not categorized as genocide, children born of war/genocide endure challenges with identity. See Myriam Denov et al., “The Intergenerational Legacy of Genocidal Rape: The Realities \& Perspectives of Children Born of the Rwandan Genocide," Journal of Interpersonal Violence (2017), 1-22, https://doi-org.mutex.gmu. edu/10.1177/0886260517708407; family and community stigma, see Myriam Denov and Atim Angela Lakor, "When War Is Better Than Peace: The Post-Conflict Realities of Children Born of Wartime Rape in Northern Uganda," Child Abuse and Neglect, 65 (2017), 255-265; Myriam Denov and Atim Angela Lakor, "Post-War Stigma, Violence and 'Kony Children': The Responsibility to Protect Children Born in Lord's Resistance Army Captivity in Northern Uganda," Global Responsibility to Protect 10, no. 1-2 (2018), 217-238; and socio-economic marginalization, see Denov \& Lakor, When War is Better; Myriam Denov et al., "Mothering in the Aftermath of Forced Marriage and Wartime Rape: The Complexities of Motherhood in Post-War Northern Uganda." Journal Of Motherhood Initiative 9, no. 1 (2018), 158-176. This research underscores that there may be more similarities than differences, thus challenging the need for such categorical distinctions.

${ }^{5}$ Maggie Zraly et al., “Motherhood and Resilience among Rwandan Genocide-Rape Survivors,” Ethos 41, no. 4 (2013), 411439.

${ }^{6}$ Emily Wax, "Rwandans Are Struggling to Love the Children of Hate," The Washington Post, March 28, 2004, accessed October 10. 2019, https://www.washingtonpost.com/archive/politics/2004/03/28/rwandans-are-struggling-to-love-

Myriam Denov, Laura Eramian and Meaghan C. Shevell. "You Feel Like You Belong Nowhere': Conflict-Related Sexual Violence and Social Identity in Post-Genocide Rwanda." Genocide Studies and Prevention 14, 1 (2020): 40-59. @2020 Genocide Studies and Prevention.

https://doi.org/10.5038/1911-9933.14.1.1663 
area of scholarly attention, initial research has shed light on the complex lives and needs of this group, particularly the discrimination and rejection children born of war and genocide face as a result of their stigmatized identities and origins. ${ }^{7}$ However, research has generally examined the experiences of these two groups - children born of conflict-related sexual violence and their mothers - in relative isolation. To foster a more holistic exploration, this article addresses the central research question of how both children born of rape and their mothers grapple with identity and social belonging in the post-genocide political context of national reconstruction and the outlawing of ethnic identities. This approach recognizes the significance not only of everyday relationships, networks, and norms, but also of the broader political context of post-genocide Rwanda in shaping the lives and social identities of families formed from the sexual violence of the genocide.

This article takes a multi-disciplinary approach that combines perspectives from social anthropology, social work, and human rights studies. Our aim is not to elucidate a particular "process" of identity formation, since how people configure who they are and how they belong is never a singular, coherent, or linear path of change, nor a fait accompli. Rather, by drawing on indepth interviews and focus groups with forty-four Rwandan mothers and sixty youth, our analysis reveals two key sets of tensions in their experiences of identity, selfhood, and social belonging. First, at the interpersonal level, while youth often sought to learn about their birth origins and fathers to better understand themselves and their histories, mothers actively avoided discussing their past in an effort to disentangle their identities from sexual violence and genocide. Second, at the level of larger post-genocide politics, both mothers' and childrens' identities are caught in the rigid ethnic politics of the genocide, a view of ethnicity the Rwandan Patriotic Front (RPF)-led government's project of national unity and reconciliation actively seeks to erase. Youth experiences show how the identities of their (mostly) Hutu perpetrator fathers continue to be imposed on them, which challenges their ability to claim the unified "Rwandan" identity central to the RPF's narrative of post-genocide recovery. Our analysis ultimately shows the distinction between the personal level of everyday social life, and the larger politics of post-genocide Rwanda are not easily distinguished, ${ }^{8}$ as challenges faced by these families exist at the nexus of the personal and the national, the individual and the structural.

The article consists of five parts. First, we outline key issues around sexual violence and social identity in Rwanda and other, similar contexts. Second, we situate our work in the broader politics of post-genocide reconstruction and, particularly the government erasure of ethnicity in Rwanda. Third, we present the study's methodology, emphasizing a socio-ecological approach. Fourth, we provide extensive extracts from our interviews with both mothers and youth to illustrate the two central tensions outlined above. Finally, we conclude by discussing both the theoretical and practical implications of our analysis.

Identity, Belonging and Conflict-Related Sexual Violence

Social identity is a central site for understanding the effects of armed conflict on both individuals and communities, ${ }^{9}$ because identities are not static, unitary, or merely what people choose for themselves, but rather emerge relationally through ongoing social interaction. ${ }^{10}$ Indeed, social anthropologists argue all selves are configured in some sense through relations with others - this,

children-of-hate/dd942c7b-9287-42cc-8763-bd0675c0b73f/; Jemma Hogwood et al., "'I Learned Who I Am': Young People Born from Genocidal Rape in Rwanda and Their Experiences of Disclosure," Journal of Adolescent Research 33, no. 5 (2018), 549-570.

${ }^{7}$ Charli Carpenter, Born of War: Protecting Children of Sexual Violence Survivors in Conflict Zones (Bloomfield, CT: Kumarian Press, 2007); Denov et al., The Intergenerational Legacy, 1-22; Denov and Lakor, Post-War Stigma, 217-238; Sarilee Kahn and Myriam Denov, "'We Are Children Like Others:' Pathways to Mental Health and Healing for Children Born of Genocidal Rape in Rwanda," Transcultural Psychiatry 56, no. 3 (2019), 510-528.

${ }^{8}$ Laura Eramian, Peaceful Selves: Personhood, Nationhood, and the Post-Conflict Moment in Rwanda (New York: Berghahn Books, 2018), 3.

${ }^{9}$ Angela Veale and Aki Stavrou, "Former Lord's Resistance Army Child Soldier Abductees: Explorations of Identity in Reintegration and Reconciliation," Peace and Conflict: Journal of Peace Psychology 13, no. 3 (2007), 273-292.

${ }^{10}$ Fiona Shanahan and Angela Veale, "How Mothers Mediate the Social Integration of Their Children Conceived of Forced Marriage within the Lord's Resistance Army," Child Abuse and Neglect 51 (2016), 72-86. 
in spite of the prominence of the Western "folk model" of the bounded, autonomous, discrete individual that supposes who we are is a product of our own interiority. ${ }^{11}$ In Rwanda, however, a relational notion of personhood is a particularly important part of everday, common sense views of the self, as it is in many African contexts. ${ }^{12}$ In Rwandan understandings of who people are, selves are not prior to the relationships into which they enter, but instead are constituted by social networks and defined by relational roles such as parent/child. ${ }^{13}$ Taylor $^{14}$ has highlighted the relational nature of Rwandan personhood as never complete and continuously built from relations with others, including kin or exchange partners. As our analysis shows, these Rwandan views of personhood raise difficult implications for youth interviewees' selfhood, as their relationships to their (often unknown) perpetrator-fathers raise obstacles to social belonging for both youth and their mothers. As our analysis shows, the difficulty is that both knowing and not knowing one's father raise their own problems for these youth, and neither is conclusively preferable.

There are a wide range of potential psychological, social, cultural, political, and economic costs for survivors of conflict-related sexual violence, ${ }^{15}$ which can interact in complex ways to challenge and undermine their well-being, self-identity, and sense of belonging. Women survivors of conflict-related sexual violence experience profound hardships, including experiences of disequilibrium that may prompt a crisis of self-identity. ${ }^{16}$ Moreover, in Rwanda and elsewhere, women who are raped often experience a drastic reduction in their societal value and status within their communities. As part of normative cultural traditions, especially where value is ascribed to women's sexual "virtue," this can negatively impact marriage suitability of women who have been raped. ${ }^{17}$ Consequentially, social stigma may hinder women's ability to access arable land and income-generating activities typically acquired through marriage, thereby undermining their livelihood opportunities. ${ }^{18}$ Furthermore, for girls, loss of virginity through rape may challenge a potent rite of passage for group membership and womanhood. ${ }^{19}$ Thus, as is the intended effect of conflict-related sexual violence, experiences of wartime and/or genocidal rape can fundamentally challenge victims' statuses and roles as community members and can significantly affect mothers' relations with their children born of rape. ${ }^{20}$

Research on conflict-related sexual violence in multiple cultural contexts has demonstrated rape may not only rupture mothers' sense of selfhood, it also profoundly affects the ethnic and

${ }^{11}$ Mary Douglas and Steven Ney, Missing Persons: A Critique of the Personhood in the Social Sciences (Berkeley and Los Angeles: University of California Press, 1998), 8.

${ }^{12}$ John L. Comaroff and Jean Comaroff, “On Personhood: An Anthropological Perspective from Africa," Social Identities 7, no. 2 (2001), 267-283.

${ }^{13}$ Eramian, Peaceful Selves, 6.

${ }^{14}$ Charles Taylor, Milk, Honey, and Money: Changing Concepts in Rwandan Healing (Washington, DC: Smithsonian Institution Press, 1992).

${ }^{15}$ Anjalee Kohli et al., "Family and Community Rejection and a Congolese Led Mediation Intervention to Reintegrate Rejected Survivors of Sexual Violence in Eastern Democratic Republic of Congo," Health care for women international 34, no. 9 (2013), 736-756; Jocelyn T. Kelly et al., "Experiences of Female Survivors of Sexual Violence in Eastern Democratic Republic of the Congo: A Mixed-methods Study," Conflict and health 5, no. 25 (2011), 1-23; Rebecca M. Loya, "Rape as an Economic Crime: The impact of Sexual Violence on Survivors' Employment and Economic Well-being," Journal of interpersonal violence 30, no. 16 (2015), 2793-2813; M. Brinton Lykes and Erzulie D. Coquillon, "Psychosocial Trauma, Poverty, and Human Rights in Communities Emerging from War," in Critical Psychology: An Introduction, eds. Dennis Fox et al., (Thousand Oaks, CA: Sage Publications, 2009), 285-299.

${ }^{16}$ Susan J. Brison, “Outliving Oneself: Trauma, Memory, and Personal Identity," in Gender Struggles: Practical Approaches to Contemporary Feminism, ed. Kathryn Pyne Addelson (New York: Rowman \& Littlefield, 2002), 137-165.

${ }^{17}$ Inger Skjelsbaek, The Political Psychology of War Rape: Studies from Bosnia and Herzegovina (London: Routledge, 2012), quoted in Janine Natalya Clark, "A Crime of Identity: Rape and Its Neglected Victims," Journal of Human Rights 13, no. 2 (2014), 146-169; Villia Jefremovas, "Loose Women, Virtuous Wives, and Timid Virgins: Gender and the Control of Resources in Rwanda," Canadian Journal of African Studies 25, no. 3 (1991), 378-395; Leah Woolner et al., "'I Asked Myself If I Would Ever Love My Baby': Mothering Children Born of Genocidal Rape in Rwanda," Violence Against Women 25, no 6 (2018), 1-18.

${ }^{18}$ Denov et al., The Intergenerational Legacy of Genocidal Rape; Donatilla Mukamana and Petra Brysiewicz, "The Lived Experience of Genocide Rape Survivors in Rwanda," Journal of Nursing Scholarship 40, no. 4 (2008), 379-384.

${ }^{19}$ Ibid., quoted in Clark, A Crime of Identity.

${ }^{20}$ Denov et al., Mothering in the Aftermath, 158-176. 
social identities of their offspring. In contexts of ethnic conflict, the stigma of rape may be passed down to children who symbolically bear the mark of both "illegitimacy" and the "enemy" through biological association with their perpetrator fathers. ${ }^{21}$ The paternal heritage of children born of conflict-related sexual violence is a potent marker of their identities, one that can endure across their life span. ${ }^{22}$ Seto notes in her discussion of children born of wartime rape in contexts around the world that, despite their blamelessness in the circumstances under which they were born, youths' ascribed identities are representative of an "enemy," ultimately rendering them "highly politicized subjects." ${ }^{23}$ These imposed, stigmatizing identities carry lasting consequences with negative social and practical implications, including children's exclusion from key social institutions and resources such as marriage, social and familial networks, and access to school, employment, or inheritance. ${ }^{24}$ Scholars have also demonstrated that these children's birth origins significantly affect their sense of self. ${ }^{25}$ For Rwandan children born of conflict-related sexual violence, their selfhood is riddled with tension and contestation, since the relations between parents and children that constitute personhood are, in their case, infused with a violent past. As a result, youths' experiences of their relational identities with respect to their mothers, siblings, wider communities, and their (usually absent) fathers are inherently ambivalent. ${ }^{26}$ Even when children do not know their fathers' identities or the truth about their origins, a lack of knowledge of their roots is itself a serious barrier to belonging in their communities ${ }^{27}$ Not knowing their paternal roots "erase[s] half of the child's identity," since key relations constitutive of their personhood are unknown, which can also exclude them from paternal inheritance. ${ }^{28}$ However, discovering the truth surrounding their conception is by no means strictly positive, since research in multiple contexts has shown affected youth have reported they "no longer felt the same" or feel split between their "old life" prior to their discovery and their "new life" after learning their birth origins. ${ }^{29}$

In sum, youths' and mothers' stigmatized identities have real implications. The culture of silence and stigma produces the perception that youths' very existence is taboo. However, it is not just at the level of interpersonal relationships that families formed from sexual violence find themselves entangled in the contradictions of the genocide's legacies, but also at the level of national politics and reconciliation initiatives.

\section{Ethnicity, Past and Present in Rwanda}

In post-genocide Rwanda, the tensions between mothers' and youths' selfhood are shaped by a larger set of politics, namely, the intersections of the ethnic politics of the genocide with the RPF's current policies of reconciliation and de-ethnicization. Youth and mothers find themselves at the nexus of this difficult and complex history. In the Rwandan context, politics have always been infused with the question of ethnic difference because ethnicity - or its erasure - has long been at the center of debates about modern nationhood and who the rightful leaders of Rwanda

\footnotetext{
${ }^{21}$ Grace Akello, "Experiences of Forced Mothers in Northern Uganda: The Legacy of War," Intervention 11, no. 2 (2013), 149-156; Myriam Denov, "Children Born of Wartime Rape: The Intergenerational Realities of Sexual Violence and Abuse," Ethics, Medicine \& Public Health 1, no. 1 (2015), 61-68.

${ }^{22}$ Bogdan Voicu and Ingvill C. Mochmann, "Social Trust and Children Born of War," Social Change Review 12, no. 2 (2014), 189.

${ }^{23}$ Donna Seto, No Place for a War Baby: The Global Politics of Children Born of Wartime Sexual Violence (Farnham and Burlington: Ashgate, 2013), x.

${ }^{24}$ Ibid; Denov and Lakor, When War Is Better, 255-265; Denov and Lakor, Post-War Stigma.

${ }^{25}$ Charli Carpenter, Forgetting Children Born of War: Setting the Human Rights Agenda in Bosnia and Beyond (New York, NY: Columbia University Press, 2010); Karmen Erjavec and Zala Volcic, "Living with the Sins of Their Fathers: An Analysis of Self-Representation of Adolescents Born of Rape," Journal of Adolescent Research 25, no. 3 (2010), 359-386.

${ }^{26}$ Kahn and Denov, We Are Children; Angela Veale et al., "Children of Young Mothers Formerly Associated with Armed Forces or Groups in Sierra Leone, Liberia, and Northern Uganda," in Early Childhoods in the Global South: Local and International Contexts, eds. Jacqui O'Riordan et al., (Oxford: Peter Lang, 2013), 27-48; Veale and Stavrou, Former LRA's Child Soldier Abductees.

${ }^{27}$ Carpenter, Forgetting Children Born, 36.

${ }^{28}$ Ibid., 111.

${ }^{29}$ Denov et al., The Intergenerational Legacy; Kahn and Denov, We Are Children.
} 
Denov, Eramian and Shevell

are, whether the traditional Tutsi elite or the Hutu majority. ${ }^{30}$ When Belgian colonists established rigid patrilineal descent rules and identity cards in the 1930s that governed what ethnic category a person belonged to, sharp new inequalities emerged between Tutsi and Hutu, particularly unequal access to education and high-ranking posts in the colonial governance apparatus, which up until independence, were by and large reserved for the sons of the Tutsi elite. ${ }^{31}$ It was these ethnic inequalities that were infamously invoked in the anti-Tutsi propaganda of the early 1990s in the campaign to mobilize the Hutu population in support of the government that eventually perpetrated the genocide.

In the aftermath of the genocide, the RPF outlawed ethnic self-identification, removed ethnicity from national identity cards, and proclaimed all citizens should unite under a single national Rwandan identity. ${ }^{32}$ The controversies around the government's program of de-ethnicization, unity, and reconciliation, and its political agendas are well established in the critical literature, ${ }^{33}$ so we do not review them all here. What is crucial is that the lives of mothers who were raped and their children support a key finding of the post-genocide scholarship, namely how ethnic difference persists and continues to shape the post-genocide period in spite of RPF reconciliation policies. ${ }^{34} \mathrm{As}$ such, mothers who were raped during the genocide and the children they bore find themselves at an awkward juncture. These families remain symbols of the ethnic politics of the genocide, because they are products of systematic rapes by (mostly) Hutu men that targeted Tutsi and "moderate" Hutu women. As our data shows, youth and their mothers continue to have these ethnic labels (or ethnically-marked monikers, like "child of the interahamwe") imposed on them in a moment when they are no longer politically acceptable. Thus, even as many Rwandans recognize de-ethnicization policies as problematic, that does not mean youth and mothers might not simultaneously value them for reasons beyond compliance with state policy. ${ }^{35}$ For example, de-ethnicization might favour mothers' generalized resistance to speaking about the past. Likewise, even as many youth sought the facts of their birth origins, they may also value the state erasure of ethnicity for the freedom from their "Hutu paternity" it promises. ${ }^{36}$ As we argue, and our interviews show, the selfhood of these children and their mothers are sites in which national politics and interpersonal strife intersect, in often contradictory ways that raise complex tensions around identity and social belonging.

\section{Methodology}

This qualitative research project, funded by the Social Sciences and Humanities Research Council of Canada and led by Myriam Denov, explored the lived realities of children born of genocidal rape and mothers who gave birth to them. The study sought to examine the post-genocide perspectives and experiences of these mothers and children, alongside the relationships between these two groups of participants.

The study drew upon a socio-ecological methodological framework, ${ }^{37}$ an approach used in social work and psychology that seeks to capture relational networks and realities shaping participants'

\footnotetext{
${ }^{30}$ Eramian, Peaceful Selves, 53; Marie-Eve Desrosiers and Susan Thomson, "Rhetorical Legacies of Leadership: Projections of 'Benevolent Leadership' in Pre-and Post-Genocide Rwanda," The Journal of Modern African Studies 49, no. 3 (2011), 429-453; René Lemarchand, Rwanda and Burundi (New York: Praeger, 1970).

${ }^{31}$ Ibid., 138.

${ }^{32}$ Lyndsay McLean Hilker, "Everyday Ethnicities: Identity and Reconciliation among Rwandan Youth," Journal of Genocide Research 11, no. 1 (2009), 82

${ }^{33}$ Johan Pottier, Re-Imagining Rwanda: Conflict, Survival and Disinformation in the Late Twentieth Century (Cambridge: Cambridge University Press, 2002); Scott Straus and Lars Waldorf, eds., Remaking Rwanda: State Building and Human Rights after Mass Violence (Madison: University of Wisconsin Press, 2013); Susan Thomson, Whispering Truth to Power: Everyday Resistance to Reconciliation in Post-Genocide Rwanda (Madison: University of Wisconsin press, 2013).

${ }^{34}$ Ibid; Helen M. Hintjens, "Post-Genocide Identity Politics in Rwanda," Ethnicities 8, no. 1 (2008), 5-41.

${ }^{35}$ Laura Eramian, "Neither Obedient nor Resistant: State Narrative as Cultural Resource in Post-Genocide Rwanda," Journal of Modern African Studies 55, no. 4 (2017), 623-645.

${ }^{36}$ Laura Eramian and Myriam Denov, "Is It Always Good to Talk? The Paradoxes of Truth-Telling by Rwandan Youth Born of Rape Committed During the Genocide," Journal of Genocide Research 20, no. 3 (2018), 1-20.

${ }^{37}$ Myriam Denov and Brie Akesson, Children Affected by Armed Conflict: Theory, Method, and Practice (New York: Columbia University Press, 2017); Neil Boothby, "Political Violence and Development: An Ecologic Approach to Children in War Zones," Children and Adolescent Psychiatric Clinics of North America 17, no. 3 (2008), 497-514.
} 
lives. This framework underscores that people's lives are characterized by overlapping spheres of family, community, society, nation, and state that are difficult to disentangle, and therefore cannot be considered in isolation. In line with this socio-ecological approach and to ensure that community perspectives were incorporated in the research design, the research team organized in-depth community consultations prior to beginning data collection in the three districts of Rwanda where the research was to be carried out. The consultations sought to engage a broad scope of family and community members who hold experiential and/or expert knowledge on the issue of children born of the genocide and their mothers, including youth born of the genocide, mothers who were rape survivors, extended family members of youth and mothers, religious/ community leaders and organizations, elders, and organizations working on transitional justice, women's rights, and children's rights issues. These participants took part in small and large group discussions to offer their perspectives on relevant research questions, research design, appropriate methods, and approaches to undertake during the course of the research. The consultations were held with a total of sixty-seven people: twenty-seven in Region 1; eighteen in Region 2; and twentytwo in Region 3. The consultations provided vital guidance to the research team and ensured the study explored what these community members felt was most important in relation to the topic. This included a focus on 1) identity; 2) stigma, belonging, and social exclusion; 3) family structure and support; 4) the development of appropriate psycho-social interventions; and 5) long-term community reintegration.

Following the community consultations, in-depth interviews were conducted between June and August 2016 with forty-four mothers of children born of genocide rape, and sixty youth (twenty-nine females and thirty-one males). Mother participants were aged between thirty-three and fifty-two. At the time of interviews, youth participants were either twenty or twenty-one years old, with the exception of one participant, who was nineteen. ${ }^{38}$ In addition to interviews, youth participants took part in a focus group. A total of seven focus group discussions were held with eight youth participants in each group..$^{39}$ While interview questions aimed to better understand the life story of each participant, focus group questions were centered around the collective challenges and needs, sources of support, and the rights of youth born of genocidal rape. Interviews and focus groups were audio-recorded with participants' permission. Local researchers conducted interviews in Kinyarwanda, while Canadian researchers used English with simultaneous EnglishKinyarwanda translation.

A snowball sampling procedure was used to recruit mother and youth participants. Participants resided in one of three regions of the country, which were selected by the research team in order to explore the similarities and differences of youth and mothers in both rural and urban settings. To protect the identities of participants, they are only referred to in categorical terms, e.g. "mother participant," or "youth participant, male." Interview and focus group audio files were translated and transcribed from Kinyarwanda to English. A grounded theory approach to data analysis was employed, whereby through careful reading and coding of transcripts, the researchers identified key themes that emerged from the data. ${ }^{40}$ An ongoing discussion of emerging themes by the research team was part of the data analysis process.

This study received approval from two research ethics boards: the first from the Rwandan National Ethics Committee, and the second from the Research Ethics Board of McGill University. Given the profound ethical implications of interviews and participant disclosures, as a selection criterion, youth respondents were required to have already been aware they had been born of genocidal rape prior to participating in the research, although the depth of information they had around their origins and histories varied. Since participants were being asked questions about their lives that had the potential to both revive traumatic memories and cause significant distress, psychosocial support structures were established in advance, in the event a participant should become distressed and require a referral. With participants' permission, researchers followed up post-interview on an ongoing basis to check on and support participants' wellbeing. To ensure support beyond standard ethical protocols, our research team offered monthly group counseling sessions for youth participants following their participation in the study. Led by a local Rwandan psychologist who was part of the research team, the group counseling was free of charge and available to all youth participants for eight months following data collection. Mothers were also 
invited to contact the psychologist following their interviews for additional support.

\section{Youth Identities: Seeking to Explore the Past}

In this section, through the voices of our youth participants, we explore key themes related to their ambivalent experiences of identity. These include: 1) stigma, discrimination, and exclusion; 2) quests for the facts of their birth; 3) silence, shame, and avoidance; and 4) belonging and recognition. In examining youths' experiences, we show how their identities are inextricably linked with their fathers, the violent past, and politically-charged ethnic labels. We highlight how youth participants' identities appear to be deeply entangled within two vexing relational tensions, which, as the socio-ecological approach suggests, are difficult to fully separate. ${ }^{41}$ First, at the interpersonal level, youths' desire to explore the past is largely in conflict with their mothers' efforts to silence the past, further exacerbating tensions within the family. Second, at the level of the nation, children born of genocidal rape find themselves in a difficult relationship to the national genocide narrative that compels people to "coexist" in a reconciled society where ethnicity does not exist, even as their identities remain enveloped by ethnic identity politics.

Stigma, Discrimination, and Exclusion

All youth participants reported multiple experiences of stigma, discrimination and/or exclusion based on their connections to their perpetrator fathers. For example, labels assigned to these youth included "child/son/daughter of a killer," and other links with the interahamwe youth militias. These labels directly or implicitly linked youth participants with the violent acts their fathers perpetrated against their communities during the genocide. This often translated into youth "inheriting" the blame and being perceived as if they were their fathers. Youths' experiences and perspectives underscored how, through daily interactions, their identities as children born of conflict-related sexual violence challenged their ability to belong not only within their communities, but also within their own families:

If your dad killed people during the genocide and your dad is not here, people are seeing you as if you are him. You may find the people you interact with... are the one that your dad killed their families... (Focus group participant)

The part that hurts me the most is being called a son of a killer... they do, like calling me a child of a killer. (Youth participant, male)

One day when I was with other children who are neighbours, one child called me "interahamwe". What I knew was that interahamwe were killers during genocide against Tutsi. So, I went home and told my mother about what happened to me. Instead of talking, she cried a lot. (Youth Participant, female)

It wouldn't even be your mother's family only [that is rejecting you] but your father's family too. You feel like you belong nowhere. (Focus group participant)

The quotations above also highlight how children's identities in their families and communities are deeply embedded within and connected to their perpetrator fathers, and with them, the ethnic divisions of the past. Furthermore, some youth revealed even their mothers were instigators of stigma and discrimination. As youth already felt ostracized by their wider communities, stigma and rejection by their own mothers was particularly distressing:

I was four years old when my young brother was born. Then my mom was calling me a bastard. Then

I was growing in that situation and was feeling not loved. (Youth participant, male)

${ }^{41}$ Boothby, Political Violence and Development. 
[My mother] does not love me, she is even calling me "interahamwe"... Here I was sad, because life was very difficult. During this period I realized that I don't have a father, I was harassed by my relatives. (Youth participant, male)

For many, the effects of marginalization as a result of their birth origins meant facing decreased opportunities for education and economic support, lack of care and affection, and in many cases, physical abuse. Participants linked physical abuse directly to their birth origins as children born of genocidal rape and/or their perpetrator fathers:

My stepfather was beating me, hurting me and calling me a bastard as well. He was even telling me to go to see my dad. (Youth participant, male)

Here, it is when I used to be beaten by my aunt. And when I was fifteen years old I asked my mum about my father and she was angry with me. [Crying] Here they used to ask me to do all the housework and to stay at home. I could not go to play with other children. In that case I was beaten. (Youth participant, female)

Youth participants thus bore the ethnic identities of their perpetrator fathers that are linked to a stigmatized "enemy other." These youth's "inherited" Hutu identities were particularly politicized in the context of Rwanda's post-genocide de-ethnicization policy under which ethnic labels are equated with a divisive genocide ideology. This fraught politics of ethnicity ultimately challenged their sense of belonging in the current political moment characterized by a "Rwandan" nation:

I want them to treat me as Rwandese without asking me if I am a Hutu or a Tutsi. (Youth participant, male)

These imposed ethnic labels further complicated participants' identities and challenged their ability to understand and accept themselves:

Here we lived at [place] and I remember that I was in secondary school and it is when I heard many bad things like I was Hutu... I was confused they were saying that my mother has children who are Tutsis and others who are Hutus and I didn't know what was that. And it was hard to accept myself, I had a complex, I started feeling ashamed between others. And hearing people saying that my father is Hutu, he killed people in the 1994 genocide...that was hard. (Youth participant, female)

Quests for the Facts of their Births

For many youth participants, stigmatization, differential treatment, and exclusion within the family and community triggered a desire for a deeper investigation into their origins. Differential treatment within the family, especially among siblings, alongside a lack of knowledge about their origins, made participants feel "different" and prompted questioning of their identities:

My half siblings are light skinned, as you see I am black skinned and I had neighbors that were always talking about how I was not their brother because we don't look alike, some were saying that they took me in an orphanage, others that they took me from the street and when I heard that I started being curious of my origins and my mother told me. (Youth participant, male)

I asked them the reason why my father (....) people from my father's side never visit us. Then they told me they said they can't come to our house because we are not the same. We don't belong to the same ethnic group. Because my father raped my mother in 1994. And soon afterwards she died. Because I needed to know my family from my father's side, I went to ask them and then they told me I am not related to them. They asked me to leave - to go to my home. (Youth participant, female)

I am always asking my mom why she didn't want to be with us while she has got other children that she is raising as a caring mom, but not us. I am always wondering why she doesn't want to tell us who is our father, nor even raising us as her own children. (Youth participant, male) 
We also have difficult to accept [sic] ourselves because we don't know our origins. We don't know our fathers and their families. So it becomes a problem for us. (Focus group participant)

Yes, our mum treats us [siblings] differently. She is caring [with] them. At home, she wants me to do heavy activities, even to cultivate our land. They are fifteen and twelve years old respectively. My mother seems to be unhappy with me. (Youth participant, female)

For youth participants, lack of knowledge and/or connection with their paternal origins was a potent missing piece in their relational selfhood ${ }^{42}$ that posed an obstacle to feeling they belonged in their social worlds. These questions about their origins often resulted in youth participants embarking on what they referred to as a "quest for the truth" at some point in their lives. Youth spoke about questioning the circumstances surrounding their conception, the identity of their fathers, extended family members, and their family's genocide experiences. For most participants, discovery of the truth was a pivotal moment in their lives that both provided sought-after answers and raised new complications in their sense of themselves. As these participants explained:

I really wish to know my dad's history. It is sad at our age to say that we don't know anything about our father... Our wish is to know him, his history, we would be happy. As of now... we don't know his family, we don't know anything about him which is not normal. (Youth participant, male)

Before I knew the way in which I was born, I did not have any problem. When I learnt about my story, I felt a lot of change inside, and I realised the reason why my mother was always angry with me, using harsh words against me for any small mistake, especially during memorial period. Now I understand her reactions. She suffered a lot during genocide against Tutsi. I have accepted it since I know the truth. (Youth participant, female)

The best thing that makes me happy is to live with my mom. The worst is to live without any information about my father. (Youth participant, male)

In line with the socio-ecological perspective, youth interviews suggested discussions around their birth origins and paternal roots were extremely important for a participant's conception of self, their relational identities, building the mother-child relationship, and most importantly, for accepting themselves:

We don't know anything about our father, yet we have someone who knows and who shall tell us the truth but does not want to do so... Yet if our mother told us the truth, we could accept our situation. (Youth participant, male)

For me it is a problem to live without knowing your father - especially when he is alive. (Youth participant, female)

${ }^{42}$ Taylor, Milk, Honey, and Money, 5. 
These youths' perspectives speak to how, in the Rwandan context, one cannot "be someone" without knowing how they are enmeshed in relations with others. ${ }^{43}$ Indeed, people are thought to "produce each other," through exchange, sharing substances like food and drink, and the transmission of "parts" of parents into their children. ${ }^{44}$ However, as these youth explain, they struggle to know where they fit in their social worlds when they do not know their fathers, while at the same time, revelations of those details can present challenges of their own through stigma and marginalization.

Silence, Shame and Avoidance

As a result of the deeply entrenched stigma attached to their birth origins, many youths reported how discussions with their mothers and extended families on their birth origins were taboo and surrounded by silence. Their mothers, who sought to avoid speaking about painful pasts, often met their quests for the truth with silence and discomfort:

When I was young, I was living with my mother and I used to ask her why I don't see my father in our home. She did not tell me anything, instead she was avoiding it... On my side, when I was young, she used to hide [any information about] my history. She was telling me that my dad died. But later she told me the truth on how she was raped and how I was born. (Youth participant, male)

As long as she doesn't want to talk about our Dad, I mean who he was, how he died, it's not going to work with us... I don't know my biological father. I heard that he died during the genocide but to be honest what affects me the most is that my mom doesn't want to tell me who is my father ... I am always wondering why she doesn't want to tell us who our father is, nor even raising me as her own child. (Youth participant, male)

Several youths reported their mothers were still too negatively affected by the past to discuss it, with some mothers expressing they did not want to "go back in time" to such a traumatic period of their past:

When I came back from [place] I didn't sleep the whole night I was crying. In the morning I asked my mother for a pen and she told me that she doesn't have a pen but you can see clearly that she didn't want to talk to me. I went to school, coming back to school I didn't go home I went to my grandmother's house. I woke up the next morning and I went back home. After a week, I asked my mother to tell me what really happened and she told me to stop making her go back in time. She cried. So from that day, I decided to stop asking about it. (Youth participant, female)

There's a lot I want to ask her [mother] but when I try to ask her, she acts as if she does not want me to ask her about it...I think that when I ask her about it, the whole past story comes back into her life and it really disturbs her a lot. (Youth participant, male)

I asked that question [about my father's origins] to my mother and she seems to avoid to go into details. She told me that what she knows is that he raped her and this affected her. I also asked my aunt who is not living with us and she told that my father is known and is there [alive]. (Youth participant, female)

For some youth participants, hearing the truth from their mothers rather than through gossip, insults, or discrimination was vital. Youth participants often expressed that not receiving "an adequate answer" from their mothers troubled their own sense of self, and it was also a strain on the mother-child relationship:

Another thing is a bad relationship with you and your mother because of the things she has been through and how she doesn't want to talk about it and you, you are curious to know what happened, so you are getting mad at each other. (Focus group participant) 
She [mother] has never taken time to tell me about my story. Instead, I was told this by other people from our family... Maybe she is still affected, but also, on my side it affects me by the fact that I am living without knowing the truth from my mother. But I hear people talking about my story, so it is a problem. (Youth participant, female)

It was important because I wanted to know the truth from her not from other people. (Youth participant, male)

Several youths explained how lacking information on their paternal ancestry negatively affected their overall sense of wellbeing. For some, the silence about their origins and histories instigated what participants often referred to as a "complex" riddled with uncertainty regarding who they were and where they belonged:

The other thing is to always hear others talking about their dads but you don't even know who is your real father, it is painful. (Focus group participant)

There is a problem of feeling isolated, feeling not accepted in family as other children. (Focus group participant)

However, in balancing their needs and their desire to protect their mothers, some youth described how they eventually stopped asking their mothers for answers because of their strong emotional reactions:

Every time I have tried to ask her [about my origins], she was always angry with me, so I decided to leave it because it is like she is traumatized (Youth participant, male)

She [mother] has sacrificed her life for me, she has been a good mother for me, when everyone abandoned her for me, she didn't left [sic] me, she continued to love me unconditionally... She treats me good as her child, her sister and as her best friend because we talk about everything, the only thing she doesn't want to tell me it is her genocide problems but I think it is because she feels ashamed for that. (Youth Participant, female)

We didn't talk about many things [about my origins] because I saw that she was crying too much, and I stopped asking her questions. (Youth participant, male)

Youth Belonging and Recognition

In terms of the socio-ecological linkages between identity and larger national politics, interviews revealed being granted official recognition as victims of the genocide was crucial for youth participants' sense of belonging. In an effort to usher in transitional justice, reconciliation, and recovery in post-genocide Rwanda, the government initiated a development program to compensate survivors of the genocide for the destruction of life, property, and livelihoods. ${ }^{45}$ This program included The Genocide Survivors Assistance Fund/Fonds d'Assistance pour Rescapés du Génocide (FARG), established in 1998 to provide financial assistance to Tutsi survivors of the genocide committed from October 1st 1990 until December 31st 1994. While this fund helped to support women survivors of rape committed during the genocide, it did not include their children born from such rapes. Youth participants in this research project overwhelmingly called for an official acknowledgement by the Rwandan government as a group in Rwandan society whose origins are inextricably linked to the genocide. Many described how they believed their current life situation was a direct result of the genocide, circumstances that made their lives "different" from those of other young people. In other words, while young people recognized they were not "survivors" of the genocide according to the RPF's criteria, many considered themselves "victims"

${ }^{45}$ FARG, Republic of Rwanda. “Historical Background of FARG," accessed October 10, 2019, http://www.farg.gov.rw/ index.php?id=11. 
of genocide crimes perpetrated against their mothers and families:

Why can't people understand that we are victims? Youth [who currently receive support from the government, e.g. genocide survivors]... have opportunities because they are recognized by the government. (Focus group participant)

Official acknowledgement of their identities and the realities they face, according to the youth, could not only foster belonging, but also counter stigma/discrimination, and help them access supportive resources:

We [youth born of the genocide] need to have all the rights that other children have. We need to know each other because we have the same problems. We need to be united, to understand each other. We also need to write our history. (Youth participant, female)

First of all, [our community and government] should see us as capable, and give us the same opportunities provided to other children. FARG does not recognize us, whereas it pays school fees for genocide survivors' children. So children of my case don't have the same opportunities as the ones provided to the beneficiaries of FARG, like being offered scholarships. (Youth participant, female)

\section{Mothers' Identity Construction: “Don't Make Me Go Back in Time”}

Two central themes emerged from interviews with mothers who bore children from genocidal rape. First, mothers sought strategies to avoid reflecting on the past because doing so made them think of the lives and relationships they might have had with their children had they not been born of rape. Second, and related, mothers had to contend with the stigma of their rape victim status and the difficulty of explaining to their children the fraught kinship relationships that they shared. All quotations in this section come from mother participants.

Mother's Experiences of Sexual Violence: A Painful Past

Mothers in this study experienced brutal forms of sexual violence, torture, and abuse during the genocide. Indeed, research has uncovered the devastating consequences for women who endured sexual violence during the Rwandan genocide and gave birth to children. ${ }^{46}$ Understanding what these women experienced and endured during the genocide enables an appreciation of why they sought to disentangle their identities from their painful pasts:

We were a group of ten girls who were raped and I was the only one who got pregnant. Three days after being raped, we were saved by "inkotanyi" [the Rwandan Patriotic Front forces]. All the girls we were together, they did their studies and they are now working. When I see them, I hide myself. When I think that I was a brilliant student, I feel so sad and lose morale.

I was raped during genocide and I got pregnant. I did not even know if I would be killed like my relatives, but I survived. I accepted my pregnancy and gave birth to her and raised her... (crying) I gave birth when I was alone. I raised her alone. Nobody helped me.

Mothers reported one of the most frequent tensions in the mother-child relationship was the fact the child reminded mothers of their experiences of sexual violence and loss during the genocide. Many mothers described how their child provoked memories of the perpetrator and sexual violence, or the loss of their family members, which were all great sources of emotional pain

${ }^{46}$ Woolner et al., I Asked Myself; Myriam Denov and Antonio Piolanti, "Mothers of Children Born of Genocidal Rape in Rwanda: Implications for Mental Health, Well-Being and Psycho-social Support Interventions," Health Care for Women International (2019), 1-16, accessed October 2019, doi.org/10.1080/07399332.2019.1571593; Mukamana and Brysiewicz, The Lived Experience; Marie Consolee Mukangendo, "Caring for Children Born of Rape in Rwanda," in Born of War: Protecting Children of Sexual Violence Survivors in Conflict zones, ed. Charli Carpenter (Bloomfield, CT: Kumarian Press, 2007), 40-52. 
and stress. Their perspectives raise the difficult implications of Rwandan relational configurations of the person in the post-genocide period, as mothers saw in their children the men who victimized them in 1994:

And the hardest part was that the person who raped me, killed my grandfather. So every day I remember that, and it is very painful. And when I see my daughter I see her father in her, even if we are laughing, I can just stop laughing because of that. There are things that you can forget but those are things that you live with and forgetting them is not easy... I am married but my husband doesn't accept her. So sometimes I think that it is her fault, the things that happened to me.

When I was seeing her [daughter], the situation I passed through during genocide was immediately coming in my mind. I was seeing the man who raped me when I was 15. Nothing was making me love her at that time... As I said, her presence was reminding me of the horrible situation I was living in during genocide. Yet I was also a child who was in need of care. Also, I was poor while raising her. When I was pregnant I was even advised to abort, but I did not do it. Now I try to tolerate her because I pray.

In relation to the larger post-genocide national reconstruction efforts, mothers reported particular distress during Rwanda's annual genocide commemoration period when they are compelled to recall the difficult past:

I don't suffer anything unusual. I feel traumatized somehow when we are in memorial period.

I'm always having a headache; I never put braids or long hair. Some people carry things on their head but me I can't. I also have emotional problems. Sometimes I can spend the whole night thinking about life, it actually happens during April of each year, sometimes I wake up in a very bad mood.

Mothers' Stigma, Silence \& Avoidance of the Past

Similar to youth participants, mothers' interviews elicit how their stigmatized status of rape victim produced profound challenges around their selfhood and social belonging in the post-genocide period. Interviews revealed mothers experienced stigma because of having been raped as well as having borne and raised a "child of the interahawme." Many mothers reported this stigma was still present at the time the interviews were conducted:

People started rumors against me that I am prostitute, that this is why I am not getting married. I was too sad.

I feel like being raped by the killers is the worst thing which took away my dignity...I feel like nobody sees me as a human being.

My mother, the neighbours, they were always talking about how I gave birth to a child of a killer. And that made me so ashamed, I didn't want to go outside.

My life was not easy, even my own family rejected me. It was too hard to see how all the families were rejecting my son. My own family was saying that my son is from killers, while [my son's] family hated me, because I accused them of being killers. All the families were telling me to abandon my son.

In contrast to many children's desire to know their pasts, histories and origins, mother participants actively sought to avoid speaking about the past. This was apparent in mothers evading disclosure of their children's birth origins and paternal roots. Most mothers highlighted the moment in which their child became inquisitive about their birth origins as particularly distressing. During these discussions, which were mostly initiated by their children, mothers not only faced difficult memories, but were also challenged to have conversations that had the potential to completely alter 
their relationship. While mothers reported many different reasons for not telling their children the facts of their birth origins, many believed that having such a discussion would ultimately be hurtful to their child and to the mother-child relationship:

It's a sensitive issue to raise... he can't bear it. He can't accept it... He does not need it [to know his origins]. He uses my father's name as his father.

He already hates the people who killed others. I thought if he knew that his father was among the killers, it may affect him.

I waited until she was grown up [to tell her]. Because I did not want her to be affected.

[What makes it hard to tell him?] I fear he may ask me many questions like "how can you not know my father?" And he may think I am a bad mom. And he doesn't ask me [about it].

In the preceding quotations, mothers express they are compelled to keep silent about their children's birth orgins not just because of potential difficulties at the interpersonal level, but also at the levels of community and the politics of reconciliation. As such, several mothers also revealed they lacked the courage to tell their children directly about their origins:

[Do you feel you can tell him the truth?] I am not able to do it.

No, it is not possible, I don't have the courage [to tell my son]...I pray a lot for that but I am not sure I will be able to do it...

\section{Discussion: Tensions in Identity in Post-Genocide Rwanda}

Two central and interrelated tensions emerge from the interview findings, ones that elucidate how legacies of genocide find expression at multiple levels. ${ }^{47}$ First, mothers and youth found themselves in a fraught relationship to the past and to each other. While youth often sought information about their fathers, mothers resisted speaking about the past. Echoing previous research on mothers who gave birth to children born of conflict-related sexual violence, ${ }^{48}$ our research found mothers experienced profound forms of stigma, violence, marginalization, and shame. The stigma of having been victims of genocidal rape was compounded by the perceived identity of their children as belonging to the interahamwe. ${ }^{49}$ In the Rwandan context, the consequences for families formed from this sexual violence are especially severe, as perpetrators were often neighbours of their victims and thus continue to be a difficult presence (yet also absence) in the lives of mothers and youth. As a result, many mothers believed withholding information from their children on their experiences of sexual violence and their child's birth origins could shield them from family and community stigma.

Youth born of genocidal rape and their mothers shared experiences of stigma and marginalization from family and community members, but differed in that for youth, stigma was

${ }^{47}$ Boothby, Political Violence and Development.

${ }^{48}$ Woolner et al., I Asked Myself; Kahn and Denov, We Are Children.

${ }^{49}$ It is important to note the family and community linking a child born of conflict-related sexual violence to their perpetrator father has been found in multiple contexts around the globe including northern Uganda, see Denov and Lakor, When War is Better, 255-265; for Rwanda, see Marie-Eve Hamel, "Mediated Voices: Nation/State Building, NGOs and Survivors of Sexual Violence in Postconflict Rwanda and Bosnia-Herzegovina, 2016, accessed October 10, 2019, https://www.era.lib.ed.ac.uk/handle/1842/23509; for Bosnia, see Karem Erjavec and Zala Volcic, "Living With the Sins of Their Fathers: An Analysis of Self-Representation of Adolscents Born of War Rape,"Journal Of Adolescent Research 25, no. 3 (2010), 359-386, accessed October 10, 2019, https://doi.org/10.1177/0743558410361373; and for Sierra Leone, see Myriam Denov, Child Soldiers: Sierra Leone's Revolutionary United Front (Cambridge: Cambridge University Press, 2010), highlighting similarities of experiences for children born of conflict-related sexual violence across contexts. 
linked to their ethnic birth origins whereas for mothers it was linked to their status as victims of sexual violence. Youth reported struggling to belong in a context where they were often intrinsically linked to their perpetrator fathers, and often regarded as ethnically Hutu. Youth sought to understand their mothers' experiences during the genocide, and their own birth origins, however painful and uncomfortable. These quests for the truth about their origins, their fathers, and their histories are entangled in core tensions in post-genocide Rwanda around past and present, disclosure and silence, family and politics. Knowing what happened to their mothers during the genocide and knowing the identities of their perpetrator-fathers was imperative for youth in trying to understand who they are and how they belong. The trouble, of course, is that their perpetrator fathers are precisely the source of their stigma and rejection, and so, both knowing and not knowing their fathers posed obstacles for youths' identity and belonging in their social worlds. ${ }^{50}$

Second, mothers and youth are reluctant symbols of the violent past and the ethnic politics of the genocide. At the level of national politics, scholars have shown how ethnicity continues to matter against state policies of de-ethnicization. ${ }^{51}$ Ethnic distinctions were unwelcome impositions on youth participants, who had grown up in post-genocide Rwanda where ethnic labels are outlawed. In the context of the RPF's attempts to "re-educate" Rwandans on their history through local sensibilisation meetings, the ingando solidarity camps, ${ }^{52}$ formal education in schools, and reconciliation workshops, people know the importance of adhering to the RPF's official line on ethnicity as a colonial invention that all "good Rwandans" must eschew in the post-genocide period. As such, when others saddle these youth with inherited paternal ethnic identities, the youth are caught in a subject position that puts them at odds with the state narrative which says all citizens are Rwandans, not Tutsi or Hutu. What the experiences of these mothers and youth lay bare is how the legacy of the genocide "catches" these families in old ethnic politics and sometimes imposes Hutu and Tutsi or other ethnically marked distinctions (e.g. "child of interahamwe") on them. Indeed, interviewees sometimes invoked Tutsi or Hutu labels in describing their experiences - a language largely taboo in "post-ethnic" Rwanda - but they nonetheless relied on to communicate their hardships. While the government's unity campaign has been heavily critiqued as a mode of silencing political dissent and legitimating RPF rule, ${ }^{53}$ it nonetheless produces the narrative of ethnicity Rwandans must adhere to in order to have a place in the larger story of post-genocide nation-building and by extension, to claim to be modern citizens for whom "parochial" matters like ethnicity no longer matter. ${ }^{54}$ As such, the ongoing significance of inherited ethnic identities for families formed of sexual violence means they struggle to belong not just at the level of kinship and community, but also at the level of the national politics of reconstruction. Youth struggle with the Hutu ethnic identifiers they inherited from their fathers and that make them politicized subjects in their social worlds. And while there is no question many Rwandans resist the RPF's politics of reconciliation, ${ }^{55}$ the lives of these youth and their mothers highlight that participants are not only compelled to navigate an imposed political project, like national de-ethnicization, but are, in many ways, excluded from it.

A further complication of youths' latent Hutu identities in the post-genocide period is that they are not officially considered "victims of the genocide" according to FARG's criteria for financial assistance. Not only were they born after 1994, but their patrilineal heritage is typically Hutu, not Tutsi, both of which exclude them from survivor status. The state approach to victimhood thus focuses exclusively on direct victims (i.e., those Tutsi who suffered directly from human rights violations), rather than the multifaceted implications of histories of violence that produce indirect

\footnotetext{
${ }^{50}$ See also Eramian and Denov, Always Good to Talk?

${ }^{51}$ See Eramian, Peaceful Selves; Hilker, Everyday Ethnicities.

${ }^{52}$ Andrea Purdeková, Making Ubumwe: Power, State and Camps in Rwanda's Unity-Building Project, vol. 34 (New York: Berghahn Books, 2015).

${ }^{53}$ Thomson, Whispering Truth to Power.

${ }^{54}$ Eramian, Neither Obedient nor Resistant.

${ }^{55}$ Thomson, Whispering Truth to Power.
} 
victims (i.e., those who suffer human rights violations as a result of their link with a direct victim). ${ }^{56}$ Moreover, children born of the genocide often experience forms of physical violence directly as a result of their birth origins and relations with their perpetrator fathers. ${ }^{57}$ Beyond the material consequences of not receiving financial support, the exclusion of children born of genocidal rape from FARG funding not only renders their challenges invisible and leaves their voices unheard, but also serves to perpetuate narratives of restricted victimhood at the state level.

\section{Conclusion}

As we argue, and as our interviews show, national politics and interpersonal strife intersect in the lives of Rwandan youth born of conflict-related sexual violence and their mothers, in often paradoxical ways that raise complex problems of identity and belonging in their social worlds. Both in Rwanda and elsewhere, identity and selfhood are formed through social relations with others..$^{58}$ What this means is that people can never simply choose for themselves who they are and how they belong, as statuses and their accompanying roles are social rather than a mere product of individual choice. However, the post-conflict situation of contemporary Rwanda puts this problem into particularly sharp focus. Even as ascribed statuses are by definition not chosen, that does not mean people cannot still desire greater autonomy in formulating their identities, as is the case when Rwandan mothers struggle against the stigmatized identities the sexual violence of the genocide imposed on them. The difficult position of mother and child-victims of sexual violence during the genocide continues to "catch" them in the politics of the past; "inherited" ethnicity continues to matter in their lives in ways that are difficult to overlook, even as it is deeply impolitic in the context of the RPF's de-ethnicitization campaign.

From an analytical perspective, what the lives of these mothers and children tell us about postgenocide Rwanda is that neither inclusion in nor exclusion from an imposed national project of unity building is conclusively preferable. Post-genocide reconciliation politics are highly constrained, and yet, being a part of them is the only way to "become someone" in the story of Rwanda's rebirth and reconstruction. ${ }^{59}$ In this way, persons and politics are deeply infused with each other in ways that might be both enabling, as RPF unity-building policies align with mothers' resistance to talking about the past, and constraining, as those same politics entangle families in an outdated view of ethnicity as an inherited property of the self and make them symbolic of the violent past. Mothers' and youths' often-incompatible responses to the violent past, ethnicity, and personhood raise important questions about the relationship between everyday social relationships and national post-conflict reconstruction projects. Indeed, the lives of Rwandan families formed from sexual violence show how difficult it is to parse out the level of the everyday from that of national politics, and it is the intricate linkages between kinship, community, politics, and social structure that render the question of what it means to have endured the violence of the 1994 genocide so complicated.

Finally, from a practice-oriented perspective, our findings may provide important insights, both for interventions in the lives of our research participants and for mothers and youth in other cases of conflict-related sexual violence. Scholars have emphasized that children born of such violence have been largely invisible in the development of national and international policies, with some governments actively repressing reports of the phenomenon in their post-war societies.$^{60}$ For the most part, policy and protection efforts have centered on women as the victims/ survivors of sexual violence and not their children born of sexual violence. This focus has often been implemented with the assumption that the benefits of programs designed for women will inevitably trickle down to their children. ${ }^{61}$ However, other researchers and advocates have argued

\footnotetext{
${ }^{56}$ Myriam Denov and Sarah Kahn, "'They Should See Us as a Symbol of Reconciliation:' Youth Born of Genocidal Rape in Rwanda and the Implications for Transitional Justice," Journal of Human Rights Practice 11, no.1 (2019).

${ }^{57}$ Denov et al., Mothering in the Aftermath.

${ }^{58}$ Janet Carsten, After Kinship (Cambridge: Cambridge University Press, 2003); Taylor, Milk, Honey, and Money.

${ }^{59}$ Eramian, Neither Obedient nor Resistant, 635.

${ }^{60}$ Carpenter, Forgetting Children.

${ }^{61}$ Virginie Ladisch, "From Rejection to Redress: Overcoming Legacies of Conflict-Related Sexual Violence in Northern Uganda," International Centre for Transitional Justice, 2015, accessed October 10, 2019, https://www.ictj.org/publication/ rejection-redress-overcoming-legacies-conflict-sexualviolence-northern-uganda
} 
that neglecting the specific dimensions of these children's vulnerabilities may result in further marginalization and discriminatory treatment. ${ }^{62}$ As such, effective policies and programming would need to both grapple with, and address, the significant tensions and challenges found in this study, particularly, the reality of mothers wanting to embrace silence in relation to the past, and in turn, children wanting to explore the past and the identities of their fathers. Post-conflict service provision and programming would thus benefit from adopting a socio-ecological lens by implementing solutions that go beyond the individual child or mother to include the multiple actors, relations, and networks at play including family, community, policy, and the nation.

\section{Bibliography}

Akello, Grace. "Experiences of Forced Mothers in Northern Uganda: The Legacy of War." Intervention 11, no. 2 (2013), 149-156. Doi: 10.1097/wtf.0b013e3283625d3c

Brison, Susan J. “Outliving Oneself: Trauma, Memory, and Personal Identity" In Gender Struggles: Practical Approaches to Contemporary Feminism, edited by Kathryn Pyne Addelson, 137-165. New York: Rowman \& Littlefield, 2002.

Boothby, Neil. "Political Violence and Development: An Ecologic Approach to Children in War Zones." Children and Adolescent Psychiatric Clinics of North America 17, no. 3 (2008), 497-514. Doi: 10.1016/j.chc.2008.02.004

Carpenter, Charli. Born of War: Protecting Children of Sexual Violence Survivors in Conflict Zones. Bloomfield, CT: Kumarian Press, 2007.

--------. Forgetting Children Born of War: Setting the Human Rights Agenda in Bosnia and Beyond. New York, NY: Columbia University Press, 2010. Doi: 10.7312/carp15130

Carsten, Janet. After Kinship. Cambridge: Cambridge University Press, 2003.

Clark, Janine Natalya. "A Crime of Identity: Rape and its Neglected Victims." Journal of Human Rights 13, no. 2 (2014), 146-169. Doi: 10.1080/14754835.2014.886952

Cresswell, John W. Research Design: Qualitative, Quantitative, and Mixed Methods Approaches. Los Angeles: Sage Publications, 2013.

Comaroff, John and Jean Comaroff. "On Personhood: An Anthropological Perspective from Africa." Social Identities 7, no. 2 (2001), 267-283. Doi: 10.1080/13504630120065310

Denov, Myriam and Antonio Piolanti. "Mothers of Children Born of Genocidal Rape in Rwanda: Implications for Mental Health, Well-Being and Psycho-Social Support Interventions." Health Care for Women International, 2019, 1-16. Accessed October 10, 2019. Doi: 10.1080/07399332.2019.1571593

Denov, Myriam. "Children Born of Wartime Rape: The Intergenerational Realities of Sexual Violence and Abuse." Ethics, Medicine \& Public Health 11 (2015), 61-68.

--------. Child Soldiers: Sierra Leone's Revolutionary United Front. Cambridge: Cambridge University Press, 2010.

Denov, Myriam and Atim Angela Lakor. "When War Is Better Than Peace: The Post-Conflict Realities of Children Born of Wartime Rape in Northern Uganda." Child Abuse and Neglect (2017), 255-265.

---------. “Post-War Stigma, Violence and 'Kony Children': The Responsibility to Protect Children Born in Lord's Resistance Army Captivity in Northern Uganda." Global Responsibility to Protect 10, no. 1-2 (2018), 217-238. Doi: 10.1163/1875984x-01001011

Denov, Myriam and Bree Akesson. Children Affected by Armed Conflict: Theory, Method, and Practice. New York: Columbia University Press, 2017. Doi: 10.7312/deno17472-002

Denov, Myriam and Sarah Kahn. “'They Should See Us as a Symbol of Reconciliation:' Youth Born of Genocidal Rape in Rwanda and the Implications for Transitional Justice." Journal of Human Rights Practice 11, no. 1 (2019), 151-170. Doi: 10.1093/jhuman/huz011

Denov, Myriam, Amber Green, Atim Angela Lakor and Janet Arach. "Mothering in the Aftermath of Forced Marriage and Wartime Rape: The Complexities of Motherhood in Post-War Northern Uganda." Journal Of Motherhood Initiative 9, no. 1 (2018), 158-176.

${ }^{62}$ Ladisch, From Rejection to Redress. 
Denov, Myriam, Leah Woolner, Jules Pacifique Bahati, Paulin Nkusi, and Obed Shyaka. "The Intergenerational Legacy of Genocidal Rape: The Realities \& Perspectives of Children Born of the Rwandan Genocide." Journal of Interpersonal Violence (2017), 1-22. Doi: $10.1177 / 0886260517708407$

Desrosiers, Marie-Eve and Susan Thomson. "Rhetorical Legacies of Leadership: Projections of 'Benevolent Leadership' in Pre-and Post-Genocide Rwanda." The Journal of Modern African Studies 49, no. 3 (2011), 429-453. Doi: 10.1017/s0022278x11000279

Douglas, Mary and Steven Ney. Missing Persons: A Critique of Personhood in the Social Sciences. Berkeley: University of California Press, 1998.

Eramian, Laura. Peaceful Selves: Personhood, Nationhood, and the Post-Conflict Moment in Rwanda. New York: Berghahn Books, 2018.

Eramian, Laura. "Neither Obedient nor Resistant: State Narrative as Cultural Resource in PostGenocide Rwanda." Journal of Modern African Studies 55, no. 4 (2017), 623-645. Doi: 10.1017/ $\underline{\text { s0022278x17000404 }}$

Eramian, Laura and Myriam Denov. "Is It Always Good to Talk? The Paradoxes of Truth-Telling by Rwandan Youth Born of Rape Committed During the Genocide." Journal of Genocide Research 20, no. 3 (2018), 1-20. Doi: 10.1080/14623528.2018.1459240

Erjavec, Karmen and Zala Volcic. "Living with the Sins of Their Fathers: An Analysis of SelfRepresentation of Adolescents Born of Rape." Journal of Adolescent Research 25, no. 3 (2010), 359-386. Doi: 10.1177/0743558410361373

FARG, Republic of Rwanda. "Historical Background of FARG." Accessed October 10, 2019 http:// www.farg.gov.rw/index.php?id=11.

Hamel, Marie-Eve. “Mediated Voices: Nation/Stae Building,NGOs and Survivors of Sexual Violence in Postconflict Rwanda and Bosnia-Herzegovina, 2016. Accessed October 10, 2019. https:// www.era.lib.ed.ac.uk/handle/1842/23509.

Hintjens, Helen M.. “Post-Genocide Identity Politics in Rwanda." Ethnicities 8, no. 1 (2008), 5-41. Doi: $10.1177 / 1468796807087017$

Hogwood, Jemma, Christine Mushashi, Stuart Jones, and Carl Auerbach. "“I Learned Who I Am": Young People Born from Genocidal Rape in Rwanda and Their Experiences of Disclosure." Journal of Adolescent Research 33, no. 5 (2018), 549-570. Doi: 10.1177/0743558417713302

Jefremovas, Villia. "Loose Women, Virtuous Wives, and Timid Virgins: Gender and the Control of Resources in Rwanda." Canadian Journal of African Studies 25, no. 3 (1991), 378-395. Doi: $10.1080 / 00083968.1991 .10803899$

Kahn, Sarilee and Myriam Denov. “'We Are Children Like Others:' Pathways to Mental Health and Healing for Children Born of Genocidal Rape in Rwanda." Transcultural Psychiatry 56, no. 3 (2019), 510-528. Doi: 10.1177/1363461519825683

Kelly, Jocelyn T., Theresa S. Betancourt, Denis Mukwege, Robert Lipton, and Michael J. Vanrooyen. "Experiences of Female Survivors of Sexual Violence in Eastern Democratic Republic of the Congo: A Mixed-methods Study." Conflict and Health 5, no. 25 (2011). Doi: 10.1186/17521505-5-25

Kohli, Anjalee, Maphie Tosha, Paul Ramazani, Octave Safari, Richard Bachunguye, Isaya Zahiga, Aline Iragi, and Nancy Glass. "Family and Community Rejection and a Congolese Led Mediation Intervention to Reintegrate Rejected Survivors of Sexual Violence in Eastern Democratic Republic of Congo." Health Care for Women International 34, no. 9 (2013), 736756. Doi: 10.1080/07399332.2012.721418

Ladisch, Virginie. "From Rejection to Redress: Overcoming Legacies of Conflict-Related Sexual Violence in Northern Uganda." International Centre for Transitional Justice, 2015. Accessed October 10, 2019.https://www.ictj.org/publication/rejection-redress-overcoming-legaciesconflict-sexualviolence-northern-uganda.

Lemarchand, René. Rwanda and Burundi. New York: Praeger, 1970.

Loya, Rebecca M. "Rape as an Economic Crime: The Impact of Sexual Violence on Survivors' Employment and Economic Well-being." Journal of Interpersonal Violence 30, no. 16 (2015), 2793-2813. Doi: 10.1177/0886260514554291 
Lykes, M.Brinton and Erzulie D. Coquillon. "Psychosocial Trauma, Poverty, and Human Rights in Communities Emerging from War." In Critical Psychology: An Introduction, edited by Dennis Fox, Isaac Prilleltensky, and Stephanie Austin, 285-299. Thousand Oaks, CA: Sage Publications, 2009.

Marcia, James E. "Development and Validation of Ego-Identity Status." Journal of Personality and Social Psychology 3, no. 5 (1966), 551-558. Doi: 10.1037/h0023281

McLean Hilker, Lyndsay. "Everyday Ethnicities: Identity and Reconciliation among Rwandan Youth." Journal of Genocide Research 11, no. 1 (2009), 82-100. Doi: 10.1080/14623520802703640

Mukamana, Donatilla and Petra Brysiewicz. "The Lived Experience of Genocide Rape Survivors in Rwanda." Journal of Nursing Scholarship 40, no. 4 (2008), 379-384. Doi: 10.1111/j.15475069.2008.00253.x

Mukangendo, Marie Consolee. "Caring for Children Born of Rape in Rwanda." In Born of War: Protecting Children of Sexual Violence Survivors in Conflict Zones, edited by Charli Carpenter, 40-52. Bloomfield, CT: Kumarian Press, 2007.

Nowrojee, Binaifer. Shattered Lives: Sexual Violence During the Rwanda Genocide and Its Aftermath. New York, N.Y.: Human Rights Watch, 1996.

Pottier, Johan. Re-Imagining Rwanda: Conflict, Survival and Disinformation in the Late Twentieth Century. Cambridge: Cambridge University Press, 2002.

Purdeková, Andrea. Making Ubumwe: Power, State and Camps in Rwanda's Unity-Building Project. Vol. 34. New York: Berghahn Books, 2015.

Rinaldo, Rachel. "Rights-Rwanda: Women Survivors of the Rwandan Genocide Face a Grim Reality." Inter Press Service, April 6, 2004. Accessed October 10, 2019. http://www.ipsnews. net/2004/04/rights-rwanda-women-survivors-of-the-rwandan-genocide-face-grimrealities/.

Scott Straus and Lars Waldorf, eds. Remaking Rwanda: State Building and Human Rights after Mass Violence. Madison: University of Wisconsin Press, 2013.

Seto, Donna. No Place for a War Baby: The Global Politics of Children Born of Wartime Sexual Violence. Farnham and Burlington: Ashgate, 2013.

Shanahan, Fiona and Angela Veale. "How Mothers Mediate the Social Integration of their Children Conceived of Forced Marriage within the Lord's Resistance Army." Child Abuse and Neglect 51 (2016), 72-86. Doi: 10.1016/j.chiabu.2015.11.003

Sharlach, Lisa. "Gender and Genocide in Rwanda: Women as Agents and Objects of Genocide." Journal of Genocide Research 1, no. 3 (1999), 387-399. Doi: 10.1080/14623529908413968

Skjelsbaek, Inger. The Political Psychology of War Rape: Studies from Bosnia and Herzegovina. Routeledge, 2012. Doi: $10.4324 / 9780203695616$

Taylor, Charles. Milk, Honey, and Money: Changing Concepts in Rwandan Healing. Washington, DC: Smithsonian Institution Press, 1992.

Thomson, Susan. Whispering Truth to Power: The Everyday Resistance of Rwandan Peasants to PostGenocide Reconciliation. Vol. 34, Madison: University of Wisconsin press, 2013.

Veale, Angela and Aki Stavrou. "Former Lord's Resistance Army Child Soldier Abductees: Explorations of Identity in Reintegration and Reconciliation." Peace and Conflict: Journal of Peace Psychology 13, no. 3 (2007), 273-292. Doi: 10.1080/10781910701471306

Veale, Angela, Susan McKay, Miranda Worthen, and Michael G. Wessells. "Children of Young Mothers Formerly Associated with Armed Forces or Groups in Sierra Leone, Liberia, and Northern Uganda." In Early Childhoods in the Global South: Local and International Contexts, edited by Jacqui O’Riordan, Deidre Horgan \& Shirley Martin, 27-48. Oxford: Peter Lang, 2013.

Voicu, Bogdan and Ingvill C. Mochmann. "Social Trust and Children Born of War." Social Change Review 12, no. 2 (2014), 189-212. Doi: 10.1515/scr-2015-0005

Wax, Emily. "Rwandans Are Struggling to Love the Children of Hate." The Washington Post, March 28, 2004. Accessed October 10, 2019. https://www.washingtonpost.com/archive/ politics/2004/03/28/rwandans-are-struggling-to-love-children-of-hate/dd942c7b-928742cc-8763-bd0675c0b73f/. 
Woolner, Leah, Myriam Denov and Sarilee Kahn. "'I Asked Myself If I Would Ever Love My Baby': Mothering Children Born of Genocidal Rape in Rwanda." Violence Against Women 25, no. 6 (2018), 703-720. Doi: 10.1177/1077801218801110

Zraly, Maggie, Sarah E. Rubin, and Donatilla Mukamana. "Motherhood and Resilience among Rwandan Genocide-Rape Survivors." Ethos 41, no. 4 (2013), 411-439. Doi:10.1111/etho.12031 